\title{
Robert Rogowski
}

State University of Applied Sciences in Nowy Sącz

Institute of Economics

e-mail: rogowskir@wp.pl

\section{The practice of CSR implementation in Polish companies according to the CSR advisors*}

\begin{abstract}
The paper presents the experiences of advisers in implementing the concept of CSR in Polish enterprises. The article presents the results of surveys covering such issues as the implementation of CSR motives and actions taken by operators in the implementation of CSR policies. CSR advisors also identified that companies can use unethical practices. This is also a characteristic of CSR advisors.
\end{abstract}

Keywords: CSR, ethics, Polish enterprises

JEL Classification: M14

\section{Introductory remarks}

The concept of corporate social responsibility (CSR) dates back to the midtwentieth century. In 1953, Bowen, with his book entitled Social Responsibilities of the Businessman ${ }^{1}$ made the discussion about the idea of responsibility connected with business activity more dynamic, which in time, turned into the concept of

\footnotetext{
* The article is an updated version of the paper published in Polish in the Annales. Ethics in Economic Life, 19(1), 37-54.

${ }^{1}$ In 2013, a new edition of this book was published at the University of Iowa. The author writes about CSR as follows (p. 6): "It refers to the obligations of businessmen to pursue those policies, to make those decisions, or to follow those lines of action which are desirable in terms of the objectives and values of our society."
} 
CSR (Corporate Social Responsibility) (p. 6). There are many CSR definitions. They include its social, economic, political or environmental aspects. The authors who take up this topic use such terms as: ethical practices, environmental protection, and transparency in actions, consideration of all parties involved, responsibility, responsible behavior, moral obligations, or corporate social responsibility.

It should be noted that the motives for CSR implementation in enterprises may be different, starting from a pure business calculation (CSR as a certain management strategy that allows maximizing economic benefits), through trend, the pressure of the environment (competition or consumers who enforce CSR implementations), the possibility of using financing and consulting in the implementation of CSR, or pure care resulting from moral motives and the desire to be responsible for their actions.

As Bowen notes that business decisions have a direct impact on the lives of people in society. This impact applies only to entrepreneurs, shareholders, employees or clients, both directly and indirectly. Economic life always takes place in society and only then makes sense. It is in a society that products and services are provided. It is in the society that clients are sought for, whose acquisition and maintenance determines the continuity and development of a business. Enterprises make a significant contribution to the common good by hiring employees, manufacturing goods, providing services and paying taxes. It is entrepreneurs who are the basic and indispensable subjects of economic life. Each entrepreneur is "the creator of new techniques, raw materials, goods as well as new needs. His activity is creatio ex nihilo: it is overcoming the imperfections of knowledge and discovering new possibilities taking place in the form of a creative act of noticing what remained behind the veil of ignorance" (Klimczak, 2001, p. 109).

Economic activity is one of the basic areas of human and social functioning. Its conduct is possible only in a social context, through cooperation with others. The functioning of enterprises in society means that they should not behave in any manner - they are obliged to act properly and the responsibility connected with it. Such a responsibility results from the fact that enterprises influence the situation of members of society; specific people with personal dignity, should be the subject and the goal of the whole social and economic life.

The aim of the research results presented in the article was to identify the experience of advisers dealing with the implementation of the CSR concept in Polish enterprises. The research results have been discussed in which problems such as: motives for CSR implementation, activities undertaken by economic entities in the implementation of CSR policy, and identification of unethical practices used by enterprises were taken. The article also describes the CSR advisors themselves.

The layout of the study is as follows: the first part outlines the idea of CSR briefly and demonstratively, while the second presents the results of the research. 


\section{CSR concept}

Rahman (2011) presented the evolution of defining CSR within six decades, counting from the 1950s. Initially, the duties of entrepreneurs and managers were not limited to taking actions that gave the best economic results but also taking into account the human and social aspects. Davis then justified corporate social responsibility by pointing to the consequences of their decisions, which have a broader, than only economic or technical, dimension. Frederick wrote about the need for business to take into account the expectations of society so that the effect would be to improve socio-economic well-being. In 1970, Heald described CSR as a relationship between an enterprise and the community. Even Friedman, an opponent of the CSR concept, paid attention to the need to take care of profit, but in accordance with the applicable legal principles. Subsequent CSR approaches took into account the necessity of balancing between various goals, such as profit, employee welfare, suppliers, local community or the whole nation. In the 1970s, the economic, legal, ethical and philanthropic expectations of the society towards business were pointed out. Four aspects of the social activity of enterprises appeared then: social responsibility, social accounting, social indicators, and social audit. It was further pointed out that the idea of CSR should be implemented as a free choice, as opposed to obligations arising from the law. In 1984, Freeman proposed the theory of stakeholders, in which he cataloged the stakeholders of enterprises to which he included consumers, competitors, media, journalists, suppliers, government, consumer associations, local communities, and business associations. In 1999, CSR was defined as a "contract between business and society in which society grants a license to an enterprise and in return expects responsible and acceptable practices." Next, the concept of 3P (People, Planet, Profit) was indicated as the basis for CSR, according to which what is good for the environment and for society is also good for the financial effects of economic activity. In 2002, the European Commission described CSR as a concept in which enterprises consider social and environmental aspects in their business activities on a voluntary basis. In 2001, Lantos distinguished three types of CSR: ethical (morally responsible actions that take into account the damages that the company's activities may cause), altruistic (voluntary activities of the company that may involve losses and sacrifices) and strategic (support for a society realized as an element of strategic corporate business goals). In 2007, the issue of CSR in third world countries was also taken, in which many corporations do not feel obliged to implement this concept (Rahman, 2011). In 2008, the World Business Council for Sustainable Development introduced its definition of CSR, referring to the behavior of business people in an ethical way for economic development, improving the quality of life of employees and their families, as well as local communities and society as a whole. UN Global Compact, as the world's largest UN initiative for corporate social responsibility and supporting sustainable development, undertakes actions for the sustainable development of the economy, the fight against corruption, environmental protection and ensuring social inclusion. Instead of the definition of 
CSR, it promotes the application of 10 basic principles in business. In 2011, the European Commission published a new definition defining CSR as the responsibility of enterprises for their impact on society.

The literature also distinguishes three dimensions of entrepreneurs' responsibility: the micro-plane (the attitude of the entrepreneur towards himself, the attitude towards others-employees, contractors, supervisors and the attitude to non-personal goods - for example to the natural environment), the mezo-plane (regarding the organization of economic units) and the macro-plane (covering the problems of organizing the socio-economic system, also on an international scale) (cf. Dylus, 2002, pp. 273-287). It is assumed that all dimensions should be treated as a whole-integrally. ${ }^{2}$

One can point to a few basic areas of social responsibility of the entrepreneur. These include: economic responsibility, i.e., the need to care for a positive economic result, legal responsibility and compliance with applicable law, ethical responsibility in (accordance with moral principles, and philanthropic responsibility in undertaking activities for the benefit of the society (cf. Rybak, 2002, pp. 67-69).

The economic responsibility of the entrepreneur lies in ensuring the possibility of its functioning and therefore demands taking care of a positive financial result. Thanks to this, the owner is rewarded for the risk, capital employed and work involved. Jobs are maintained, and thanks to reinvestments, there is a possibility of further development of the company. Profit means de facto contributing to the achievement of the common good (provided that it is not exploitation, i.e. a profit achieved through unfair economic activities). Profit is, therefore, a good and should be treated as a means to achieve other goals. It should serve every man, not only the owner of the enterprise but also employees and even consumers (cf. John Paul II, 1991, No. 35).

The legal responsibility of the entrepreneur means that he/she is acting within the limits of the established law. ${ }^{3}$ Assuming that legal regulations are fair, organizing socio-economic life and inhibiting immoral activities, their observance is a condition for maintaining the social order. Compliance with the law by the entrepreneur is the implementation of responsibility and contributes to the preservation of the socio-economic order.

The ethical responsibility of an entrepreneur means that as a moral being, he/she bears responsibility for all his/her actions, just as every man is responsible, regardless of the area of his activity. Therefore, the actions, or the negligence of the entrepreneur, are related to responsibility. This applies to all relationships,

\footnotetext{
${ }^{2}$ Economic ethics, asking about the scope of responsibility of the enterprise and the entrepreneur, developed a stakeholder theory. The term means "all whose interests or rights are in any way related to the activities of a given company." People who are interested are talked about, so people who are directly or indirectly affected by the company's operations. This means that they cannot be excluded from entities for which moral responsibility is taken (Dylus, 2000, p. 27).

${ }^{3}$ The definition of the law is given by F. J. Mazurek: "The law norms social relations between human persons, social groups, relations between persons and state authority, and the attitude of persons to various types of goods. It integrates social groups, sets social roles, controls actions, and defines a socio-economic system; it is experienced by entities as a claim-obligation and is a type of language expression having a specific meaning" (1973, p. 49).
} 
both within the enterprise (primarily the relations between the employee and owner) and at the interface between the enterprise and the environment (relations with suppliers, consumers, the local community, the state).

The philanthropic responsibility of an entrepreneur is going beyond mere justice and may manifest itself in engaging the enterprise in various social programs. In practice, the intentions of such actions may be utilitarian, moral or mixed (moral-utilitarian). The allocation of a part of financial resources or other support is a help for specific people and a contribution to the realization of the common good.

Garriga and Mele (2004) note that the majority of contemporary CSR theories include four basic goals of enterprises implementing the principles of corporate social responsibility. First, focus on getting long-term profits; secondly, to run a business in a responsible manner; thirdly, taking into account the expectations of society and, fourthly, contributing to the good of society through ethically correct actions.

The CSR concept was also taken into account by the ISO International Organization for Standardization, which in 2010 introduced the ISO 26000 social responsibility standard (Guidance on Social Responsibility). It defines social responsibility as the organization's responsibility for the impact of its decisions and actions on society and the environment through transparent and ethical behavior. ${ }^{4}$

Researchers note that the implementation of CSR is combined with many benefits including improving the image, translating into increased customer loyalty, greater satisfaction, and greater employee motivation, and easier access to capital. Implementation of the CSR concept may turn out to be a profitable element of corporate strategy, lowering the risk and allowing maintaining long-term relationships leading to many benefits (cf. Nur-E-Alam, 2015).

An important question about CSR is the moral evaluation of the practices undertaken. Since this is not the purpose of this study (the problem belongs to normative ethics), it is only possible to signal selected controversies or ethical answers. The moral evaluation of implementing specific solutions under CSR in practice requires answering questions: what are the motives and goals of the activities (the subjective aspect of the act)? What are the effects of the activities (the objective aspect of the act)? Are these actions real or simulated? The development of an enterprise is good in itself, and CSR is certainly an exemplification. In the case of CSR, a number of good practices are implemented for various entities related to the company. Theoretically, these themes can be purely utilitarian, or altruistic. Without going into an ethical analysis, it is worth noting that there are entrepreneurs who, although they do not formally implement CSR strategies, in practice undertake to implement various types of good towards employees, clients or people in need,

\footnotetext{
${ }^{4}$ This procedure "contributes to sustainable development, including health and the well-being of society; takes into account the expectations of stakeholders (individuals or groups who are interested in decisions or activities of the organization); it complies with applicable law and is consistent with international standards of conduct; it is integrated with the activities of the organization and practiced in its activities undertaken within its area of influence" (Polish Committee for Standardization, 2012). Guidance on social responsibility was developed by KT [Technical Committees] 305 on Social Responsibility and published on November 5, 2012.
} 
without simultaneously publicizing this fact. It is necessary to distinguish small business entities that delay or postpone the CSR implementation due to lack of time, funds, or other ongoing management issues. It is much easier for the larger enterprises with resources to engage in formalized CSR activities.

\section{Study results}

Preparing to conduct research, 281 Polish CSR advisers registered in the Polish Agency for Enterprise Development were identified, to which a request was submitted to complete a questionnaire. The research was carried out in May and June 2014. The traditional methodological problem was to obtain enough of returned completed questionnaires. For its increase, it was twice asked to participate in the research and people were offered to submit a research report. ${ }^{5}$ Taking into account the percentage of returned questionnaires (16\%), the conclusions drawn below should be treated as preliminary and further research is necessary for achieving a fuller understanding of the issues involved in the implementation of the CSR in the Polish enterprises. Measurement of morality in economic life is difficult, but its attempts to some extent approximate the truth about the ethos of Polish entrepreneurs and managers. It seems that too often there are a priori statements about the fact that in business we deal with frequent irregularities. As noted by Kahneman, Nobel laureate in the field of economic sciences, "[i]t is possible that this is a cognitive mistake resulting from the inclusion of some statistical information and media reports of evil occurring in the economic environment" (2012). Considering the imperfections of the survey using the questionnaire, it seems that the obtained research results, to some extent, certainly bring closer to broadening the knowledge about economic practice in Poland.

Answers were obtained from 46 people (over 16\%). All advisers had higher education. Of the respondents, 22 are men and 24 are women. The age structure is as follows: $33 \%$ of respondents are over 45 years old, $39 \%$ are 39 to 45 years old, $26 \%$ are from 25 to 35 years old and $2 \%$ are under the age of 25 (Chart 1).

Most answers came from advisors working in the following voivodeships: Masovian (39\%), Lesser Poland (13\%) and Lower Silesian (11\%). The remaining voivodships were represented by several advisers.

\footnotetext{
${ }^{5}$ One of the respondents, a specialist dealing with corporate social responsibility, proposed a conversation with the research implementer, which took place in July 2014 and covered the issues and practice of implementing CSR in Polish enterprises. Therefore, it can be stated that the supplement of the research was an interview with a practitioner professionally involved in the analyzed subject.
} 


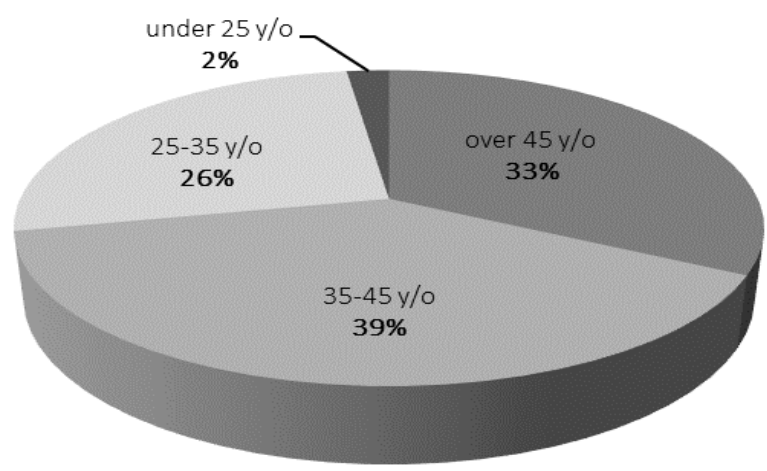

Chart 1. Age structure of the surveyed CSR advisors

Considering the advisors surveyed, they most often had an education in the field of economic sciences and / or management sciences (57\% of respondents), completed a CSR course / training (33\% of respondents), completed post-graduate studies in the field of business ethics/CSR (13\% of respondents), completed law studies ( $4 \%$ of respondents) or philosophy ( $2 \%$ of respondents). The vast majority of people declared that they had experience in business in the field of CSR (87\% of people).

In carrying out the research, attempts were made to learn the motives of dealing with CSR consulting. Some of the respondents referred to ethical categories. The following statements appeared: "The use of my competences for the common good", "Once it was called decency. Today, CSR. Each of us has the right to a dignified life, a clean environment, and a good life in the community," "I want to support these efforts to contribute to reducing the size of social alienation of companies that pursue one goal-profit," "Reaching with the message about the need to repent in the exploitation of the environment for future generations," "Willing to make companies aware that they should take responsibility for the impact they have on their environment." For some advisers, this is the realization of their professional interests (11 statements indicating the implementation of CSR as a hobby, passion, self-realization etc.). In several cases, it was a professional path resulting from previous experiences (work in the NGO sector, dealing with public relations, social work, consulting for companies in general).

Some referred to the demand reported by companies as a motive for dealing with CSR (4 responses, including e.g. "There is a growing demand for consulting in this field-very good prospects for the future"). There are rarely purely economic justifications, i.e. referring to the possibility of earning from counseling (4 people, among them the following statement: "You can earn money from it, and the effects are usually positive for everyone"). It was also pointed out that the interest of CSR on the part of a business is related to the possibility of benefiting from co-financing the implementation of this concept, with the chance to gain a better market position. The role of CSR in improving the quality of relations between employees in the workplace, increasing the effectiveness of their work 
and attracting talented young employees was also noticed. One of the advisors widely justified his work by stating that CSR was, "the ability to influence the effectiveness and quality of the company from the financial, economic, environmental, and social and employee side".

Among the respondents, only one person deals exclusively with CSR consulting. Other people work as business consultants (12 people), some are responsible for internal and external communication in the company (5 people), several people run associations, own company or manage the entrusted property ( 5 people), several people deal with employee issues, including conflict resolution, prevention of mobbing, employee volunteering, occupational health and safety, supervision of the training process (5 people), some people are connected with environmental protection (4 people), with project management in various organizations (6 people). The respondents also included: a specialist in financing and implementing economic innovations, auditors, a financier, and an appraiser.

One of the research problems was to recognize the potential economic and financial benefits as the motive for implementing CSR. In the opinion of advisers, this is a relatively frequent motive $(63 \%)$. One in three respondents said that this is probably not the main reason (Chart 2 ).

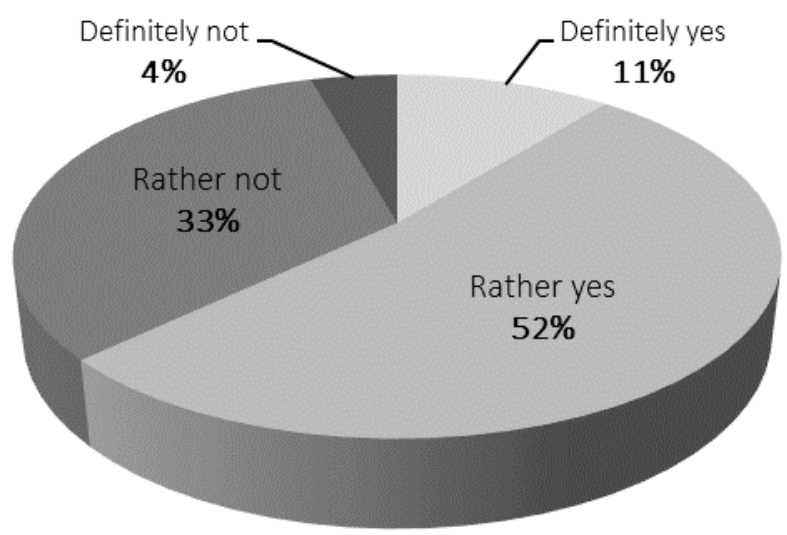

Chart 2. Implementation of CSR only due to potential economic and financial benefits

In half of the cases, the advisors stated that the motivation for implementing the CSR concept was to improve the company's image (Chart 3). 


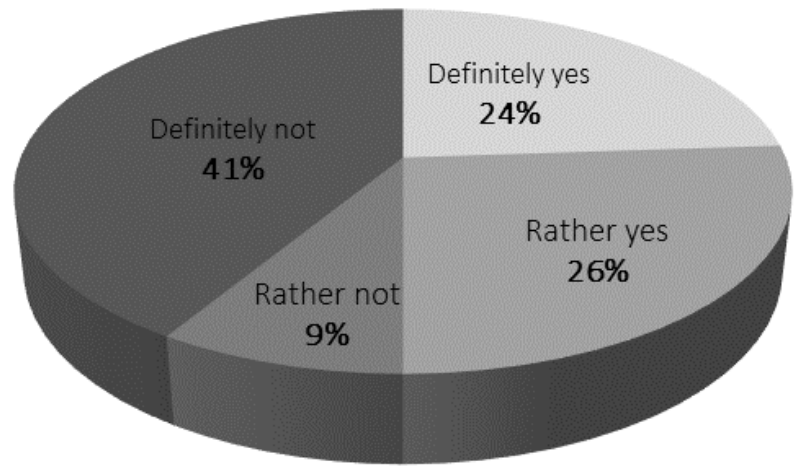

Chart 3. Implementing CSR only for the sake of improving the company's image

In $13 \%$, the implementation of the CSR concept consisted only in creating formal documentation (Chart 4).

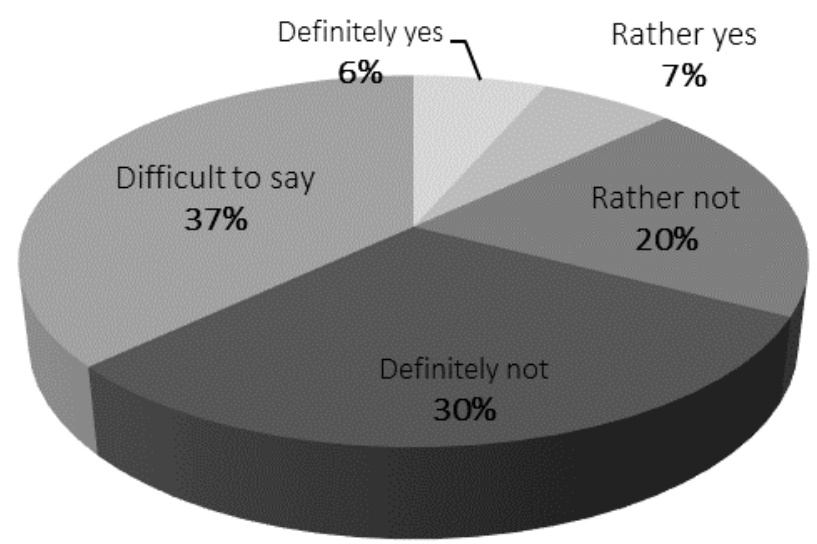

Chart 4. Implementing CSR primarily as creating formal documentation

In most cases, employees of enterprises have a positive attitude towards practices undertaken within CSR (72\%). There are also opposite opinions (Chart 5). 


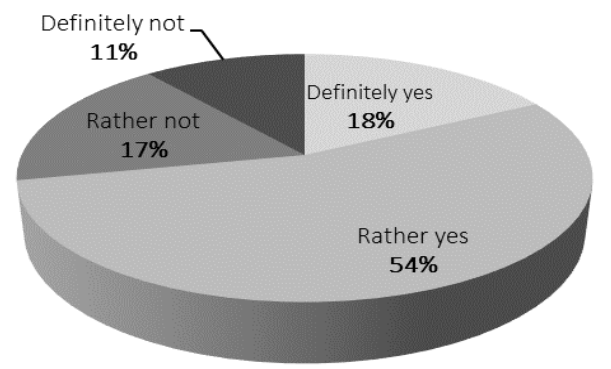

Chart 5. Positive attitude of employees of enterprises to the implemented CSR concept

It turns out that there are slightly more enterprises that actively seek external specialists asking for consultations regarding CSR (56\%). In almost half of cases, enterprises receive an offer from external institutions in the field of consulting and developing CSR strategies (Chart 6).

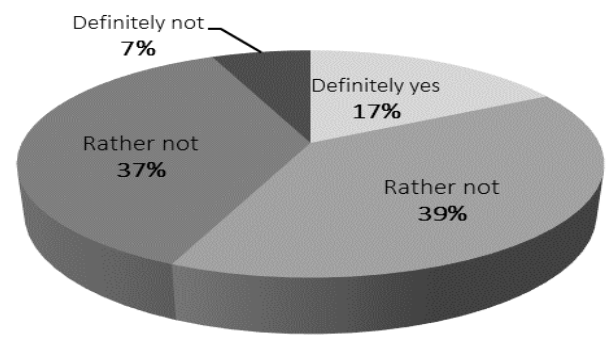

Chart 6. Enterprises applying for the CSR consultations themselves

The majority of enterprises (68\%) provide information about activities undertaken within CSR to the environment (Chart 7).

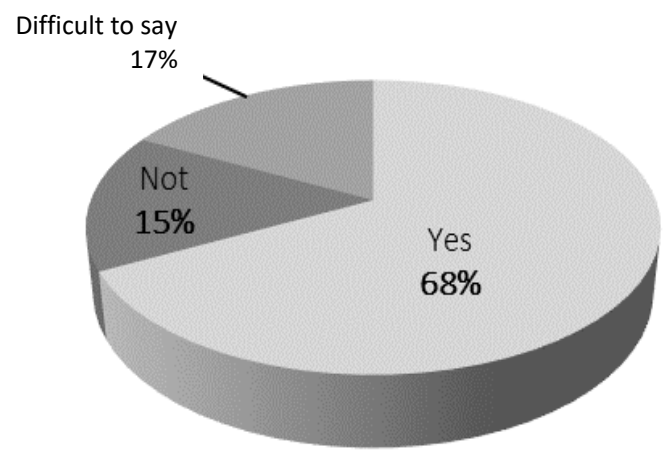

Chart 7. Informing the environment by enterprises about the activities undertaken as part of the CSR 
An interesting issue was the identification of the type of positions occupied in enterprises by those responsible for CSR. In every third case, it was the person occupying the highest position in the enterprise. Every third employee was given this additional obligation. In every fourth case, it was an independent position. In a few cases, it was an outsider (Chart 8).

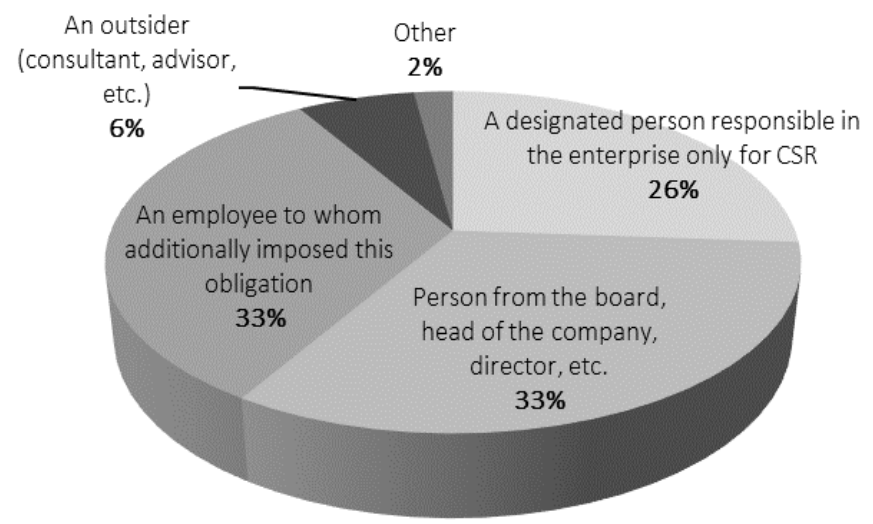

Chart 8. Posts occupied in the company by those responsible for CSR

It turned out that the bigger the enterprise, the more interest it is in the implementation of CSR. The most common were joint-stock companies (52\%), followed by medium-sized enterprises (28\%). Some respondents said $(10 \%)$ that there are no significant differences taking into account the size of the enterprise (Chart 9).

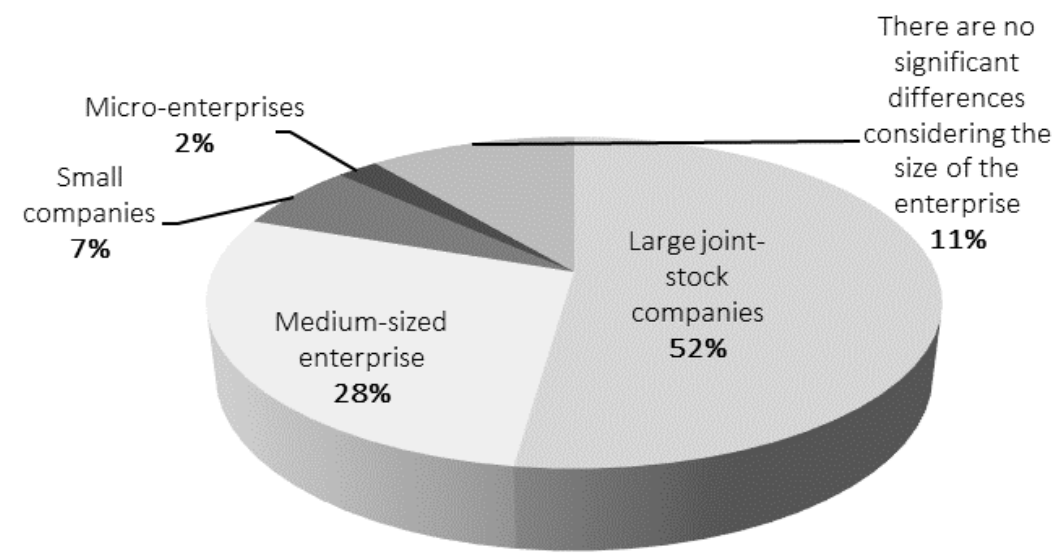

Chart 9. The type of enterprises most often interested in implementing CSR according to the size criterion 
The respondents also prioritized the motives for implementing CSR in enterprises. In top priority was to improve the image (30\%). In the second place was following the trend $(26 \%)$, the third was to improve the financial picture $(15 \%)$. The reasons such as the external requirements, willingness to implement initiatives for local communities and others were mentioned less frequently (Chart 10).

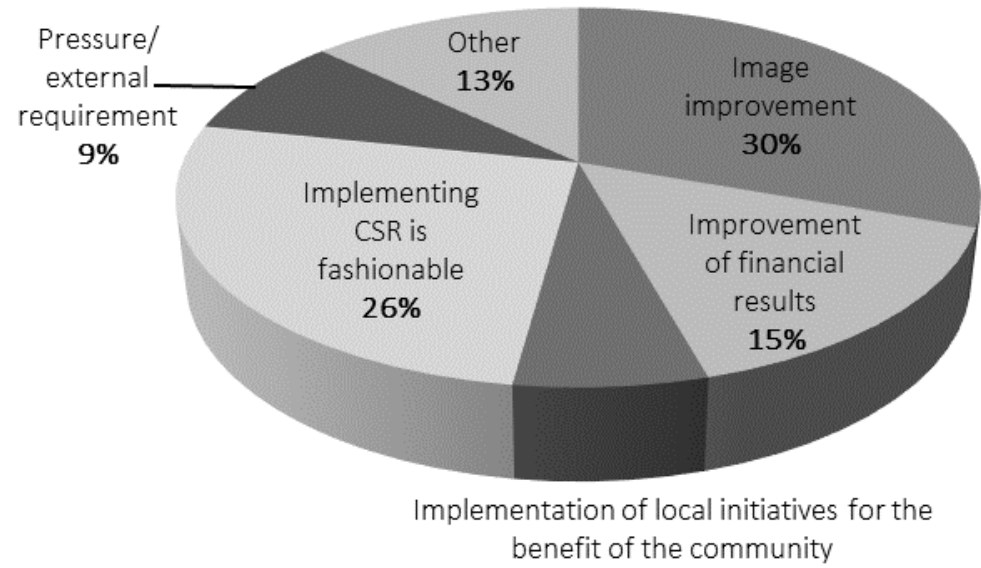

$7 \%$

Chart 10. The main theme of implementing the CSR concept

Implementation of CSR is associated with the implementation of various types of practices. Research has shown that activities such as: creation of CSR strategies $(87 \%)$, improvement of relations with employees $(72 \%)$, implementation of environmental standards (72\%), implementation of CSR strategies (65\%), and implementation of initiatives for local communities $(65 \%)$ dominate. About half of the companies these are: implementation of the code of ethics (57\%), CSR reporting $(54 \%)$, increasing work safety $(54 \%)$, charity activities $(54 \%)$ and conducting a dialogue with stakeholders $(46 \%)$. The least mentioned were, supply chain management (28\%), measuring CSR effectiveness (24\%) and counteracting corruption. (20\%). The distribution of responses is shown in Chart 11.

The aim of the research was also to learn about the most common unethical practices occurring in enterprises in the opinion of CSR advisors. The most common indications concerned, not paying overtime for employees (59\%), noncompliance with regulations regarding environmental protection (48\%), employee mobbing (43\%), non-payment of wages on time (43\%), and misleading the customers $(37 \%)$. The less frequently mentioned were: the use of unfair contract clauses (33\%), unreported employment (30\%), and avoiding taxes $(26 \%)$. At the bottom of the list were the use of whisper marketing (17\%), corruption (15\%), misleading suppliers in advertising (15\%), and the use of negative campaigning $(7 \%)$. The distribution of responses is presented in Chart 12 . 


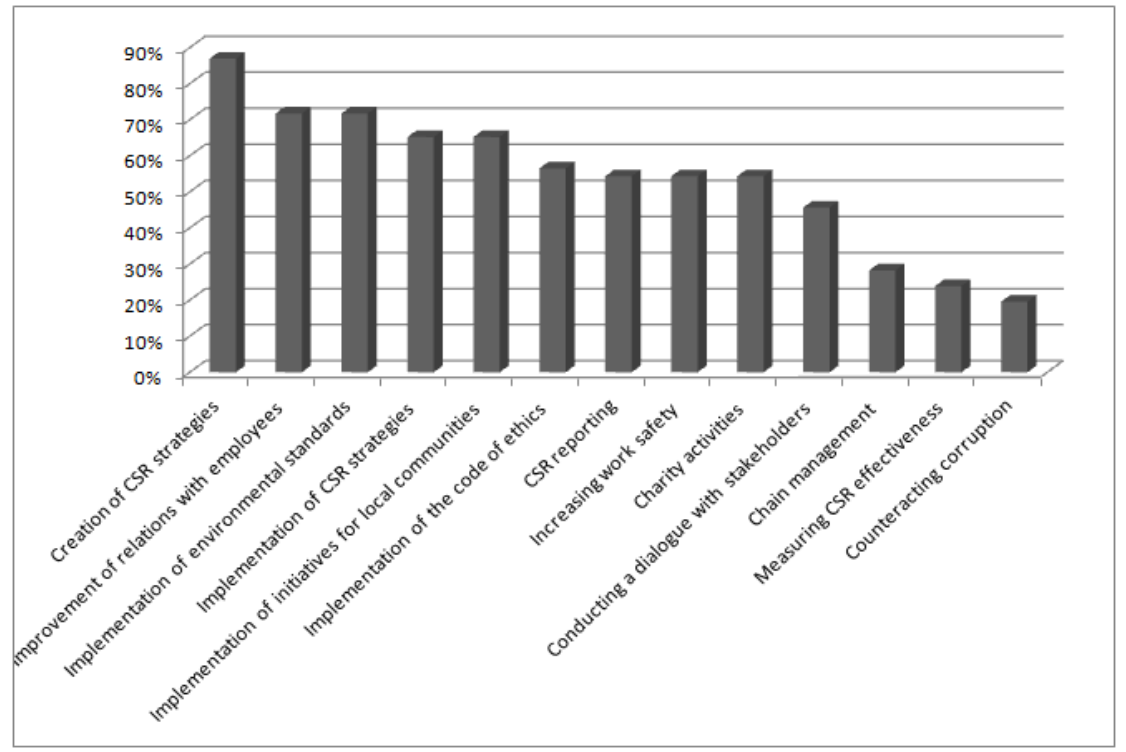

Chart 11. Activities implemented by enterprises under CSR

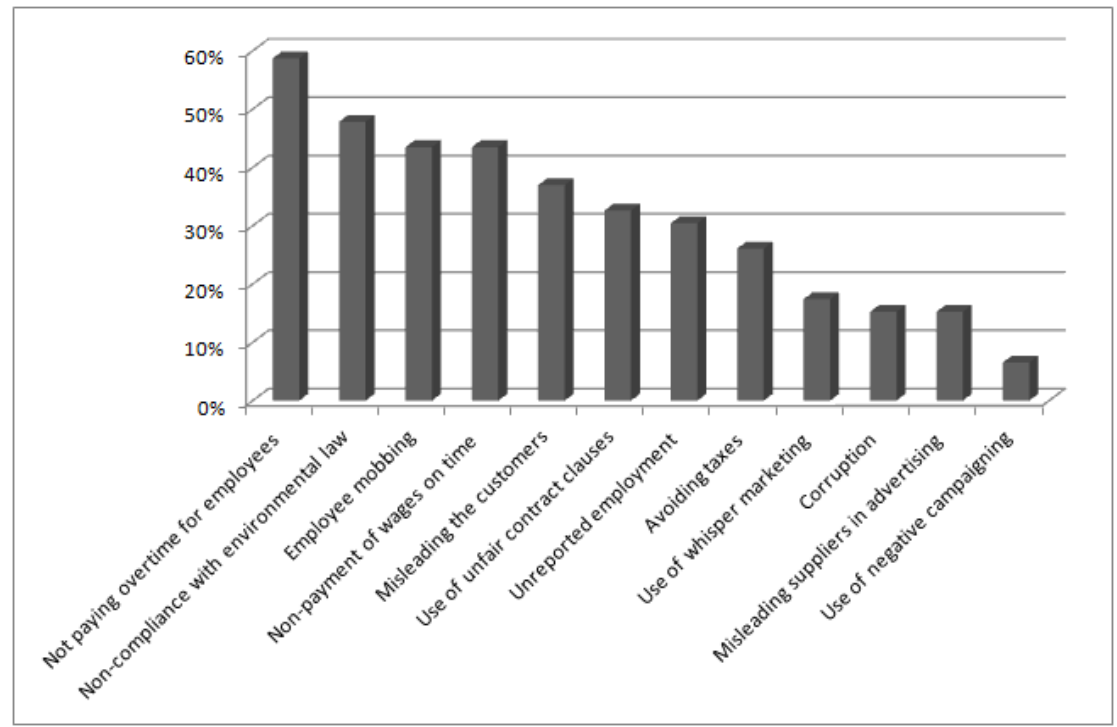

Chart 12. Unethical practices in the Polish enterprises 


\section{Conclusions}

The CSR concept has its rich history. The content itself has undergone modifications and corrections. The conducted research has brought closer the knowledge about the implementation of the CSR concept in Polish enterprises based on the experience of advisors. The main motive for implementing CSR is the potential economic and financial benefits $(63 \%)$ and the improvement of the company's image (50\%). CSR is also the trend (26\%). Implementing CSR is usually specific practical activities. Only in $13 \%$, the implementation of CSR turned out to be only the creation of formal documentation. Employees most often show a positive attitude towards CSR (72\%). The implementation of CSR in enterprises may be the result of an initiative of external entities (46\%). The majority of enterprises $(68 \%)$ use an active information policy, providing information about activities undertaken within CSR to the environment. People involved in CSR in enterprises occupy various positions. The largest interest of the CSR concept is shown by joint-stock companies (52\%) and medium-sized enterprises (28\%). Enterprises as part of CSR implementations most often create a CSR strategy (87\%), improve relations with employees (72\%), implement environmental standards (72\%), implement CSR strategy (65\%) and undertake initiatives for local communities $(65 \%)$. According to the respondents, the most common unethical practices in Polish enterprises are: non-payment of overtime (59\%), non-compliance with environmental protection (48\%), employee mobbing (43\%), non-payment of wages on time (43\%) and misleading customers (37\%).

The conducted research allows drawing several conclusions, which, what should be emphasized, are preliminary and require confronting with the results of further in-depth scientific research. It turned out that the implementation of CSR is primarily pragmatic. It should also be noted that CSR is usually specific practical activities, not limited to formal activities that would serve only informational and marketing purposes. As one might suppose, mainly large entities take active steps in implementing complex CSR strategies. Not so well is the opinion of the respondents on the scale of the most common unfair practices used by economic entities operating in Poland. However, be aware that these opinions may be the result of not only own experience, but also may be related to the previously mentioned cognitive error and a stereotypical view of business reality and not fully aware of the extent of the good that takes place in economic life.

Running a business requires effectiveness and efficiency in management. Profit, as one of the economic indicators, is a condition for the functioning of an economic entity in the long run. Apart from the economic aspect, economic activity also has a normative legal, ethical or even esthetic aspect. The entrepreneur must move in this multidimensional space, taking care of the economy. It is worth remembering that an economic entity does not have to strive to maximize profit, but it is necessary to make a profit. It should be noted here that every organization 
for its functioning must care for its financial result ${ }^{6}$. The entrepreneur, however, can make a profit by taking wicked (immoral) actions. Then one should talk about exploitation, not profit. Entering solutions offered by the CSR concept by economic entities may result from different premises and have different purposes. Certainly, it is a good thing, an added value that enriches the organizational culture of the company. Such activities can serve the development of business and promote a competitive position on the market. On the other hand, it is difficult to unequivocally assess these practices from the ethical side, especially with a superficial, image-like comparison of the "degree" of the ethicality of a given economic entity with other entities, within which various goods can be implemented without calling it CSR and without announcing it. Every human act requires a separate ethical analysis and people who carry out similar-looking business practices can be judged differently from a moral point of view.

In the future, it would be worthwhile to carry out research aimed at obtaining an answer to the question regarding the relationship between the implementation of the CSR concept and economic effectiveness in Polish enterprises. An interesting research problem would also be to diagnose the reasons for the lack of interest in the practice of CSR by small enterprises (how much the lack of resources is the cause - time, people, financial resources, as the lack of knowledge about CSR, lack of conviction regarding the legitimacy of implementing CSR in small business organizations and others).

\section{References}

Bowen, H. (1953). Social responsibilities of the businessman. New York: Harper \& Row.

Communication from the Commission to the European Parliament, the Council, the European Economic and Social Committee and the Committee of the Regions, A renewed EU strategy 2011-14 for Corporate Social Responsibility. (2011, October 25). Brussels. http://eur-lex.europa.eu/legal-content/EN/TXT/?uri=CELEX:52011 DC0681

Dylus, A. (2000). Odpowiedzialność moralna przedsiębiorców. Asekuracja\&Re, 7.

Dylus, A. (2002). Erozja standardów etycznych w biznesie. In J. Mariański (Ed.), Kondycja moralna społeczeństwa polskiego (pp. 271-297). Kraków: Wydawnictwo WAM Polska Akademia Nauk.

Garriga, E., \& Mele, D. (2004). Corporate social responsibility theories: Mapping the territory. Journal of Business Ethics 53(1), 51-71.

John Paul II. (1991). Centesimus annus.

Kahneman, K. (2012). Thinking, fast and slow, Poznań: Media Rodzina.

\footnotetext{
${ }^{6}$ A charitable organization can help financially on the scale in which it acquires funds. The household must also be managed taking into account inflows and outflows. Orders and parishes must also be managed financially. In the case of enterprises, the achievement of profits results not only from the condition of survival, but also can serve its development.
} 
Klimczak, B. (2001). Etyczne aspekty reguł konkurencji gospodarczej. In W. Gasparski, J. Dietl (Eds.), Etyka biznesu w działaniu. Doświadczenia $i$ perspektywy (pp. 100-116). Warszawa: Wydawnictwo Naukowe PWN.

Mazurek, F. J. (1973). Prawo naturalne podstawą stosunków społecznych. Roczniki Nauk Społecznych, 21(2).

Nur-E-Alam, S. (2014). CSR practices and competitive advantages: A descriptive study. American Journal of Trade and Policy, 1(2), 109-116.

Polish Committee for Standardization. (2012). Polska Norma PN-ISO 26000:2012. http:// www.pkn.pl/iso-26000

Rahman, S. (2011). Evaluation of definitions: Ten dimensions of corporate social responsibility. World Review of Business Research, 1(1), 166-176.

Rybak, M. (2002). Społeczna odpowiedzialność przedsiębiorstw. In M. Borkowska, \& J. Gałkowski (Eds.), Etyka w biznesie. Lublin: Towarzystwo Naukowe Katolickiego Uniwersytetu Lubelskiego.

UN Global Compact. https://www.unglobalcompact.org/

World Business Council for Sustainable Development (2008). http://www.wbcsd.org/ho me.aspx 